\title{
La responsabilidad en los contratos del estado: un análisis desde la ética pública
}

\author{
Recibido: 21 de enero de 2020 • Aprobado: 23 de septiembre de 2020
}

https://doi.org/10.22395/ojum.v20n42a4

\author{
Jessica Tatiana Giiechá Torres \\ Universidad del Rosario, Bogotá, Colombia \\ tatiana-guecha@hotmail.com \\ https://orcid.org/0000-0002-4298-9182 \\ Ciro Nolberto Giiechá Medina \\ Universidad Santo Tomás, Bogotá, Colombia \\ ciroguecha@hotmail.com \\ https://orcid.org/0000-0003-1462-4853
}

\section{RESUMEN}

La responsabilidad del Estado se ha enmarcado a través de títulos de imputación que van desde la responsabilidad subjetiva por la falla del servicio, pasando por la falla presunta y culminando en la responsabilidad objetiva. En esta circunstancia se determina que, en la obligación de indemnizar perjuicios como consecuencia de una falla en el servicio, existe una actuación irregular. Por otro lado, en la responsabilidad objetiva solamente es necesaria una actuación de una entidad pública y que quien sufre el daño no esté obligado a soportarlo. En cualquier caso, la responsabilidad del Estado se ha analizado desde esas dos grandes clases de atribución. Por tal razón, el presente artículo, con elfin de buscar una perspectiva distinta, tiene como objetivo estudiar la responsabilidad del Estado desde la violación de la ética pública. De esta manera, se busca determinar el fundamento de imputación de responsabilidad y la obligación de reparación de daños como consecuencia de la actividad de contratación de la Administración. Este estudio ha permitido obtener como resultados que la responsabilidad contractual del Estado se deriva, en la mayoría de las ocasiones, de la violación de postulados éticos, lo que permite concluir que la ética pública se constituye en un título de imputación de responsabilidad del Estado. En el presente artículo se ha utilizado una metodología analítico-propositiva y el método inductivo.

Palabras clave: administración; Estado; responsabilidad; ética; pública; reparación; daño. 


\section{Responsibility in State Contracts: an Analysis from Public Ethic Abstract}

\section{ABSTRACT}

The responsibility of the State has been framed through titles of imputation that go from the subjective responsibility of the failure of the service, going through the presumed failure, until culminating in the objective responsibility; circumstance that determines that in the obligation to compensate damages as a result of a failure in the service there is an irregular action, while in the objective one, only an action by a public entity is necessary, and those who suffer the damage are not obliged to bear it. In any case, the responsibility of the State has been analyzed from these two great classes of attribution. For this reason, this article, in order to seek a different perspective, aims to study it from the violation of public ethics, to determine the basis of attribution of responsibility and the obligation to repair damages, as a consequence of the contracting activity of the administration; which has allowed to obtain as a result that the contractual responsibility of the State derives in most cases from the violation of ethical postulates, which allows to conclude that public ethic constitutes a title of imputation of responsibility of the State. This article employed a propositional-analytical methodology.

Keywords: administration; State; responsibility; ethics; public; reparation; damage. 


\section{INTRODUCCIÓN}

El presente artículo corresponde al resultado de avance de investigación del proyecto denominado La actividad administrativa un mecanismo para el cumplimiento de los fines del Estado del Grupo de Investigaciones en Derecho Público de la Facultad de Derecho de la Universidad Santo Tomás de Bogotá de la línea de investigación en Derecho Administrativo. Este proyecto es financiado por dicha institución de educación superior.

La actividad de contratación por parte de las entidades públicas se ha convertido en uno de los instrumentos más usuales que el Estado utiliza para el cumplimiento de sus fines debido a que no le es posible hacerlo directamente, sino que tiene que concurrir a la ayuda de los particulares. En esta medida, su actuación se ve determinada por el cumplimiento de ciertos requisitos que se enmarcan en el adecuado ejercicio de la función pública administrativa.

En efecto, cuando una persona jurídica del Estado va a desarrollar un procedimiento de contratación, se somete a una serie de exigencias que van desde el cumplimiento de postulados de buen servicio público, pasan por el respeto de la legalidad en sentido genérico y culminan con el acatamiento de los principios éticos que deben asistir a todas las actuaciones que desarrollan las autoridades públicas.

Esto significa que los servidores públicos, cuando implementan y desarrollan un trámite de contratación, tienen la obligación de ajustarse a los principios éticos preestablecidos para que su actividad no se torne irregular. En esta contexto, se pueda generar responsabilidad del Estado en el entendido de que la actuación desarrollada cause afectaciones patrimoniales a quienes intervienen en dicho procedimiento administrativo.

Por tal circunstancia, he querido plantear la siguiente pregunta problematizadora para abordar en la investigación: ¿En qué medida la violación de principios éticos puede generar responsabilidad del Estado en el procedimiento administrativo de contratación? Para la resolución de este problema de investigación, se plantean las siguientes hipótesis:

1. La responsabilidad del Estado solo es posible por la violación de regulaciones normativas formales, es decir, contenidas en norma jurídicas.

2. Los principios éticos están inmersos en las normas jurídicas.

3 La violación de la ética pública es una fuente de responsabilidad del Estado.

Lo anterior implica que la presente investigación tiene como objetivo principal indagar cómo opera la ética pública en el procedimiento administrativo y de qué manera su desconocimiento o vulneración de principios pueden generar responsabilidad del Estado cuando, en ejercicio del procedimiento de contratación, se causan perjuicios a quienes participan en el mismo o cuando, sin haber intervenido, pueden resultar afectados patrimonialmente por actividades contrarias a la misma. 
La metodología es analítica y propositiva, y el método es inductivo. A partir del análisis particular de la ética pública y de la responsabilidad del Estado en asuntos contractuales, se llega a establecer una forma de imputación de responsabilidad del Estado a partir de la violación de principios éticos en la actividad pública de contratación.

La investigación se desarrolla en tres acápites. En la primera parte se hace una aproximación a la ética en la actividad púbica. La segunda parte se refiere al procedimiento de contratación y su determinación por principios éticos. Para culminar, el tercer apartado se refiere a la responsabilidad contractual del Estado como consecuencia de violaciones de la ética pública.

\section{NOCIÓN DE ÉTICA PÚBLICA: ENTRE EL BIEN Y EL BUEN ACTUAR}

Hablar de ética implica remontarnos a sus orígenes, esto es, lo que los pensadores griegos reflexionaron sobre este asunto. En este contexto, habrá que decir que Aristóteles (2004, p. 6) identifica la ética con el bien, es decir, con la actuación humana encaminada a lograr la felicidad. De la misma manera, Platón (2011) la asemeja al bien en el comportamiento humano, como una virtud que debe asistir siempre a las acciones de las personas, tanto en lo público como en lo privado, como una expresión de las partes del alma.

De todas formas, se trata del comportamiento de las personas, es decir, de su fuero interno que de una u otra forma se expresa o manifiesta en el mundo exterior, es decir, dentro del grupo social. Por esta razón, la ética mantiene una estrecha relación con la moral en cuanto a que esta se refleja en los comportamientos sociales que son aceptados o no como ajustados a un correcto comportamiento dentro del mismo'.

Esto significa que los comportamientos éticos hacen referencia al actuar del individuo como tal. Pero como este está inmerso en un grupo social, dichos comportamientos van a tener repercusiones respecto de las demás personas que lo integran. De esta manera, abandonan dicho fuero interno y entran a incidir en las reglas de actuación de todos los demás, impactan sobre ellas y hacen que se mantengan de acuerdo con lo preestablecido y aceptado, o las afectan en cuanto a la generación de tendencias distintas.

En tales circunstancias, los comportamientos éticos se refieren al actuar propio de las personas que están regulados por principios en caminados al "bien", es decir, a la búsqueda de un beneficio propio de acuerdo con las reglas de comportamiento que son adoptadas por el individuo, es decir, que se fundamentan en las valoraciones que la persona realiza y considera que su actuación está ajustada al concepto "bien"

1 Balmes (s. f.) llama ética a la ciencia que tiene por objeto el origen y la naturaleza de la moralidad. Por tal razón, expresa específicamente en su libro Ética: "Las ideas morales no se nos han dado como objetos de pura contemplación, sino como reglas de conducta; no son especulativas son eminentemente prácticas; por esto no necesitan del análisis científico para que puedan regir al individuo y a la sociedad" (Balmes, s. f.). 
que cada uno ha preestablecido. Esto implica que la noción de "bien" se valida por los criterios de la persona que actúa, lo que puede generar criterios diversos de lo que es considerado como "bien", es decir, ético en un supuesto de actuación.

En efecto, la fundamentación anterior podría llevar a que cada individuo se formara una percepción distinta de lo que puede considerar "bien"; lo que implicaría una total anarquía en los postulados de actuaciones éticas. Así, es posible que se diera el caso de que una persona, con el convencimiento de buscar el bien para sí, le quitara la vida a otra solo por apropiarse de sus bienes. En esta medida, el beneficio económico como una forma de "bien" para el individuo justificaría su acción. Por tal razón, es necesario encontrar una fundamentación que permita homogenizar dicha concepción en el sentido ético del término para así establecer uniformidad en las actuaciones que se pueden identificar con esta virtud, como la identificaba Platón.

Lo anterior se demuestra en el hecho de que la noción de ética en la acepción griega del término implica costumbre, puesto que proviene del vocablo ethos que así lo determina ${ }^{2}$. En este sentido, se ha identificado esta noción con el comportamiento humano reiterativo de acuerdo con ciertos principios preestablecidos que lo regulan ${ }^{3}$. El comportamiento se identifica, en el entorno de nuestra argumentación, con la noción de "bien", lo cual corresponde a un criterio de beneficio para quien actúa, es decir, para el individuo que desarrolla el comportamiento. El origen de este es volitivo, es decir, del fuero interno que surte efectos en el mundo exterior, porque quien actúa hace parte de un conglomerado social. Por esta razón, es obligatorio que dicha noción de ética, identificada como "bien" en el actuar, se ajuste a parámetros objetivos en el sentido de beneficio para cada uno y para todos los miembros del grupo social.

Esta definición implica, entonces, que sea necesario identificar una noción objetiva (dentro de las limitaciones conceptuales que pueda implicar el término) de "bien" en el actuar para establecer en qué consiste la ética en el comportamiento humano y, de esta manera, llevarlo al campo de lo público en la referencia obligada que corresponde hacer en este escrito a la denominada ética pública.

2 Al referirse al origen etimológico de la ética, Bilbeny (1992) dice: "En cuanto a su origen etimológico, la 'ética' para empezar; presenta tres ascendientes nominales. Puede por un lado, provenir del nombre éthos (con épsilon al inicio), que significa tal como hemos dicho 'hábito' o 'costumbre'. Éste [sic] es el sentido más generalizado de lo ético para los griegos. Puede, por otra parte, derivarse del sustantivo éthos (con esta o 'e' larga al principio), que significa dos cosas a la vez. Así, quiere decir 'lugar habitual' donde se vive, y, así mismo 'carácter habitual' de la persona. El ascendiente más arcaico de la palabra 'ética' coincide con este primer significado de lo ético o lo moral como expresión de la morada del hombre (Rousseau, Disc., 126; Heidegger, Carta, 127). El más nuevo se apoya, sin embargo, en la acepción de éthos como carácter del individuo agente. Ése es el sentido principal de lo ético para Aristóteles y el que a lo largo de la historia de la ética se entrelaza más a menudo con su acepción de hábito o costumbre" (p. 14).

3 Monroy (2000) afirma sobre el concepto de que es una "teoría de los actos humanos habituales ordenados de modo objetivo, en virtud de cierto principios, presupuestos o postulados por el hombre mismo" (p. 2). 
En efecto, la noción de bien se identifica, en principio, con el beneficio de quien actúa en cuanto a un comportamiento reiterativo (costumbre) en el sentido griego del concepto. Pero esta noción ha de relacionarse también con el comportamiento de los demás, ya que si cada persona tiene el mismo criterio ético, han de buscar un beneficio para sí, lo que implica la necesidad de equilibrar el beneficio o bien de uno con el de los demás. De esta manera, puede existir una objetividad en el actuar de los individuos y pueden establecerse reglas de comportamiento que se encaminen, en nuestro criterio, a un fin determinado, el cual se identifica con la noción de "bien" o lo que para algunos es lo "bueno"t.

Por tal razón, en el individuo existe lo que se ha denominado una conciencia mo$\mathrm{ral}^{5}$, Esta conciencia hace referencia a los principios que rigen el actuar de toda persona, pero que han de relacionarse con el proceder de los otros, los cuales tendrán que encaminarse a un mismo fin, es decir, lograr el "bien", lo "bueno" para todos. En este sentido, se determina la existencia de postulados idénticos o similares en lo que se debe entender por "bien o "bueno". Si estos se observan desde la perspectiva individualista, se entienden como el beneficio particular. Pero en el escenario social tiene que enmarcarse como aquello que beneficia a todos y a cada uno de quienes integran la comunidad, ya que el individuo no vive aislado, sino en relación con los demás.

En tales circunstancias, las reglas de comportamiento individual serán las que, impactando en el mudo exterior, determinen la existencia de un actuar recto ajustado a la noción de bien social. El bien social favorece a toda la comunidad y, en esta medida, entra en el campo de la moralidad porque se trata de una actuación que trasciende el mundo exterior en las relaciones entre los integrantes de la sociedad. A partir de los principios del actuar individual, los individuos aceptan o adoptan postulados generales de comportamiento que se tornan éticos debido a que, al ser comunes y reiterativos, buscan el beneficio general, entendiendo este como noción de "bien".

Lo dicho es así en la medida en que al grupo social le corresponde adoptar los criterios que se deben tener en cuenta para considerar una actuación ajustada a la ética que, al salir del plano individual, se convierte en una ética social. De alguna manera, esta ética también podría llamarse, como algunos lo hacen, moral civil ${ }^{6}$. Pero, en

4 Por tal razón, García (1977) hace referencia a que el objeto es: "la moralidad positiva, o sea, el conjunto de reglas de comportamiento y deformas de vida a través de las cuales tiende el hombre a realizar el valor de lo bueno" (p. 12).

5 García (2006), en referencia a Kant, dice: "Hay una forma de actividad espiritual que puede ser llamada 'conciencia moral' y que contienen ciertos principios por los cuales los hombres rigen su vida; estos principios son una base para formular juicios morales de sí mismos y de cuanto lo rodea [...] Kant da un nombre al conjunto de principios de la conciencia moral: 'razón práctica', término empleado por Aristóteles y después de él por muchos otros" (p. 187).

6 Cortina (2012) lo plantea de la siguiente manera: "Según una acertada caracterización de Pedro Laín, puede entenderse por "moral civil" aquella que "cualesquiera que sean nuestras creencias últimas (una religión positiva, el agnosticismo o el ateísmo), debe obligarnos a colaborar lealmente en la perfección de los grupos sociales a los que de tejas abajo pertenezcamos... Sin un consenso tácito entre los ciudadanos acerca de lo 
cualquier caso, hace referencia al acuerdo en las reglas de comportamiento dentro de la sociedad, las cuales pueden variar con fundamento en los diversos factores internos de los individuos, como externos de la conformación social ${ }^{7}$.

Pero dichos criterios o reglas de comportamiento de las personas en la sociedad adquieren el carácter público cuando se desarrollan en el Estado y en ejercicio de las funciones que a este le corresponden. Dentro de estas encontramos la función administrativa, que se expresa de forma particular en el ejercicio del servicio público por parte de autoridades igualmente públicas. Esto quiere decir que dichas reglas de comportamiento deben cumplirse en el desarrollo de las funciones estatales y, en esta medida, entramos en el campo de la ética públicå.

La ética pública no consiste en una ética distinta a la que asiste al comportamiento de los individuos y a la sociedad, sino que corresponde a una actividad especial que realiza el Estado a través de sus diversas estructuras y con unas finalidades específicas. Estas finalidades se pueden identificar en criterios tales como el servicio público, el interés general, la garantía de los derechos sociales de las personas, entre otros.

En efecto, tenemos que ubicar la ética pública en el comportamiento de quienes desarrollan actividad de servicio público. En principio, esta debe estar asistida por las reglas preestablecidas para las actuaciones personales y sociales. Ahora bien, como se trata de acciones en el marco de las funciones del Estado, se deben identificar dentro de los principios que se han adoptado para el funcionamiento del mismo. En cualquier caso, la finalidad debe ser idéntica a la de los particulares y la sociedad, como es la existencia y realización del "bien", esto es, en beneficio para quien actúa, para la sociedad y, en este caso, para quienes se refieren las actuaciones estatales, es decir, la función pública administrativa que no son más que personas y ciudadanos.

que sea esencialmente esa perfección, la moralidad civil no parece posible. La moralidad civil presupone, pues, unos ciertos ideales compartidos entre los miembros de una sociedad civil como la nuestra" (p. 182).

7 Se podría pensar que se trata en un relativismo en la noción de ética, lo cual en cierta medida lo considero cierto, ya que sus criterios determinantes son de una naturaleza dinámica aunque tengan el carácter interno o externo a las personas que actúan. La realidad social cambia así como lo hacen los individuos, personas o ciudadanos.

8 Bautista (2009) se refiere a la ética pública en los siguientes términos: "Cuando se habla de ética pública se refiere sencillamente a la ética aplicada y puesta en práctica en el ámbito público. La ética aplicada en los servidores públicos implica plena conciencia de sus actitudes la cual se traduce en actos concretos orientados hacia el interés de la ciudadanía. Implica lograr una "ética de la responsabilidad" como dijera Max Weber. La ética pública señala principios y valores deseables para ser aplicados en la conducta del hombre que desempeña una función pública. Se concibe como un área del conocimiento de contenido universal que agrupa principios y valores orientados al espíritu del servicio público. La ética pública se refiere entonces a los actos humanos en tanto que son realizados por gobernantes y funcionarios públicos en cumplimiento del deber" (p. 31).

9 Rodríguez (2012b) lo identifica de la siguiente forma: "sin pretender entrar en el fondo de la afirmación podemos afirmar que el objetivo que toda persona debe perseguir es el bien y que esa es también la finalidad de la vida pública. Una afirmación de apariencia tan genérica tiene implicaciones de orden ético y público notorias" (p. 35). 
La anterior argumentación permite indicar que la ética pública se concreta en la actuación y el proceder de los servidores públicos, quienes deben estar ajustados a los criterios, principios y valores preestablecidos, adoptados y aceptados por el Estado como una actividad que genera beneficio, es decir, "bien" para quienes conforman el grupo social dentro de las estructuras estatales. Estos principios podrían identificarse como una forma de lo que algunos han llamado virtudes públicas ${ }^{10}$, pero que igualmente es posible denominarlo como bien social ${ }^{11}$.

No obstante, en nuestro parecer, la prestación del servicio público es uno de los primeros eventos en los que se refleja la ética pública, ya que los servidores públicos deben reflejar con su actuar todos los postulados del buen proceder. Esto quiere decir que deben estar encaminados a la realización del "bien público" que se desarrolla a partir de la noción de servicio público ${ }^{12}$, en el entendido de un postulado propio de la actividad administrativa del Estado.

En efecto, la actividad del Estado se identifica con la noción de servicio público, el cual lo cumplen las autoridades públicas con una finalidad específica dentro de los parámetros preestablecidos de comportamiento ajustado a principios éticos, es decir, conforme a rectitud, honestidad, buen servicio, buena fe, entre otros, lo cual se identifica con el concepto de "bien" que hemos venido desarrollando ${ }^{13}$.

En las anteriores circunstancias, el servicio público y el actuar de los servidores públicos debe buscar el beneficio para la comunidad, en el sentido de adecuarse al interés general que ha de asistir a todas las actividades estatales. Este sentido está en consonancia con el concepto de "bien" al que se ha venido haciendo referencia y que, para efectos de la ética pública, habrá que tenerse en cuenta su identificación con el interés público como lo hacen algunos doctrinantes ${ }^{14}$.

10 En lo referente a virtudes públicas, ver Camps (2003).

11 Rodríguez (2012b) expresa: "¿Significa eso que nada podemos decir sobre el bien social, sobre el ordenamiento, la estructura social y política que debe articular nuestra sociedad? No, en absoluto. Tenemos una concepción del hombre que, en algunas de sus líneas matrices, es coincidente para la inmensa mayoría de nuestros ciudadanos, aun cuando en su fundamentación puedan ser discrepantes. Sobre esa base, sobre ese suelo firme de nuestra común concepción del hombre (que se explicita de algún modo en la declaración de los derechos humanos), es sobre lo que puede asentarse la construcción de nuestro edificio democrático" (p. 35).

12 Sobre la noción de servicio público ver Guglielmi y Koubi (2011), quienes expresan lo siguiente: "On peut considérer que le service public est une fonction á remplir et une mission á assumer, en conséquence, c'est aussi une activité concrète que certains organes prennent en charge. C'est surtout en tant qu 'activité d'intérêt général et non pas raison seulement de la qualité publique d'un organisme que la notion de service public est considérée comme l'un des fondements du droit administratif français" (p. 93). En este contexto, ver Morand-Deville (2010, p. 527).

13 Sobre ética y servicio público, ver Peña, Ausín y Bautista (2010).

14 Chapus (2001) afirma: "Une activité constitue un service public quand elle est assurée ou assumée par une personne publique en vue d'un intérêt public" (p. 579, citado por Guglielmi y Koubi, 2011, p. 93). 
Este hecho significa que el interés general en la noción de ética pública tiene una estrecha relación con el interés público, ya que en uno y otro evento se ha de identificar con el beneficio de la comunidad ${ }^{15}$, puesto que en cualquier caso se trata de la noción de "bien" para los integrantes del grupo social. Corresponde al Estado, en la forma o estructura de Estado social ${ }^{16}$, garantizar y efectivizar los beneficios comunes de todos los individuos en el marco de los criterios preestablecidos en la noción de beneficio general o de bien común en la actuación.

Estas circunstancias pueden identificarse con los derechos sociales a los que hace referencia el Estado social de derecho ${ }^{17}$, que involucran de manera sustancial los derechos fundamentales ${ }^{18}$. En nuestro concepto, los derechos sociales son los que corresponden a toda la comunidad y los derechos fundamentales son de la esencia de los individuos que conforman el grupo social, lo que determina que estos estén inmersos en los primeros, pero que los comportamientos éticos de los servidores públicos tienen que garantizar y efectivizar unos y otros.

Los derechos sociales constituyen un factor muy importante para la realización de la ética pública, en cuanto el actuar de los servidores públicos, encaminado a una finalidad de lo que hemos denominado "bien", encuentra una clara realización en dicha clase de derechos que corresponden al beneficio general. De todas formas, habrá que tener en cuenta las realizaciones individuales expresadas en los derechos fundamentales, pero con criterios que involucran principios como la igualdad, no discriminación, buena fe, confianza legítima, entre otros.

No se trata, entonces, de la ética pública como la simple concepción del actuar de las autoridades o servidores públicos en pro del beneficio general, sino de que se tienen que respetar los derechos subjetivos. Pero todo ello se debe realizar con fundamento

15 Esto es así a pesar de que ninguna doctrina identifica el interés general y el interés público, puesto que puede haber actuaciones asistidas de interés público, pero que no se enmarquen en el concepto de interés general. En este sentido, no puede ser predicada respecto de la relación de interés general e interés público, ya que siempre que exista interés general se está frente a interés público.

16 Rodríguez (2012a) expresa al respecto: "El interés general como expresión de esa voluntad general, que ya pronto Duguit se encargaría de desmitificar puesto que lo que existe en la realidad son intereses generales concretos aunque partan de un aspecto amplio que conecta con los grandes principios y parámetros del Estado social y democrático de derecho. Desde esta perspectiva, el interés general es la expresión de la voluntad general, que se confiere al Estado la suprema tarea de atener el bien de todos y cada uno de los ciudadanos" (p. 4).

17 Villar (2007), haciendo una referencia a la sentencia C-587 de 1992 de la Corte Constitucional de Colombia, dice sobre el Estado social de derecho: "En el Estado social de derecho-que reconoce el rompimiento de las categorías clásicas del Estado liberal y se centra en la protección de la persona humana atendiendo a sus condiciones reales al interior de la sociedad y no del individuo abstracto-, los derechos fundamentales adquieren una dimensión objetiva, más allá del derecho subjetivo que reconoce a los ciudadanos" (p. 94).

18 Villar (2007) se refiere a los derechos sociales en el Estado de la siguiente manera: "Como Estado social se define aquel que acepta e incorpora al orden jurídico, a partir de la propia Constitución, derechos sociales fundamentales junto a los clásicos derechos políticos y civiles" (p. 82). 
en postulados, criterios o principios preestablecidos por el grupo social para la garantía y realización del "bien", que en nuestro caso se realiza en las conformaciones estatales.

Tal vez es posible afirmar que la ética pública se involucra en el actuar de las autoridades públicas que buscan el beneficio general de todas y cada una de las personas que integran el grupo social, es decir, del "bien" que ha de tener el carácter público con un sentido de interés general a través de la garantía de los derechos sociales e individuales.

Una vez hecho el análisis de algunos criterios sobre la ética pública, es preciso adentrarnos en la influencia que esta tiene en el procedimiento de contratación del Estado, el cual corresponde a una de las expresiones de la función administrativa y que se ha constituido en un aspecto significativamente neurálgico en las vulneraciones de los postulados de buen actuar de la Administración pública.

\section{EL PROCEDIMIENTO dE CONTRATACIÓN DEL ESTADO DETERMINADO POR LA ÉTICA PÚBLICA}

El procedimiento administrativo de contratación está asistido de una serie de principios que determinan un correcto actuar de la Administración. Para tal fin, se involucran criterios de ética pública, en cuanto constituyen regulaciones obligatorias que deben cumplir los servidores públicos para el logro de los fines del Estado que son perseguidos con la colaboración de los particulares ${ }^{19}$.

En efecto, la contratación pública constituye una función administrativa y, en tal circunstancia, está sometida por los principios que corresponden a la misma, tanto en el ámbito constitucional ${ }^{20}$ como legal formal ${ }^{21}$. Pero el hecho de tener una naturaleza

19 Quinche (2015) se refiere a los derechos fundamentales en los siguientes términos: "Chinchilla define los derechos fundamentales como derechos humanos constitucionalizados y con garantía reforzada. Afirma este autor que 'son derechos humanos que han adquirido la positivización necesaria, preferentemente en el orden constitucional, y que, por lo tanto, logran un alto grado de certeza y posibilidad garante efectiva, propias de lo que tradicionalmente se conoce con la expresión de derecho subjetivo'... El titular de estos derechos es la persona individualmente considerada, en la medida en que son el fruto de la doctrina liberal, cuyo elemento central es el individualismo" (p. 105).

20 El artículo 2 de la Constitución Política de Colombia (1991) establece los fines del Estado de la siguiente manera: "Son fines esenciales del Estado: servir a la comunidad, promover la prosperidad general y garantizar la efectividad de los principios, derechos y deberes consagrados en la Constitución; facilitar la participación de todos en las decisiones que los afectan y en la vida económica, política, administrativa y cultural de la Nación; defender la independencia nacional, mantener la integridad territorial y asegurar la convivencia pacífica y la vigencia de un orden justo. Las autoridades de la República están instituidas para proteger a todas las personas residentes en Colombia, en su vida, honra, bienes, creencias, y demás derechos y libertades, y para asegurar el cumplimiento de los deberes sociales del Estado y de los particulares".

21 El artículo 209 de la Constitución colombiana (1991) contempla los principios de la función administrativa, así: "La función administrativa está al servicio de los intereses generales y se desarrolla con fundamento en los principios de igualdad, moralidad, eficacia, economía, celeridad, imparcialidad y publicidad, mediante la descentralización, la delegación y la desconcentración de funciones. Las autoridades administrativas deben coordinar sus actuaciones para el adecuado cumplimiento de los fines del Estado. La administración pública, en todos sus órdenes, tendrá un control interno que se ejercerá en los términos que señale la ley". Estos principios son igualmente previstos en el sistema jurídico español, cuando el artículo 103 de la Constitución (1978) expresa: "1. La Administración pública sirve con objetividad los 
especial recoge principios particulares de la contratación estatal en los términos previstos en el Estatuto de Contratación Pública22.

Estos principios reflejan, de una u otra forma, los postulados éticos que han de cumplir las actuaciones de los servidores y autoridades públicas en el trámite de los contratos del Estado que, como lo dijimos claramente en acápite anterior, deben encaminarse al "bien"; es decir, al beneficio de la comunidad y de los individuos que la integran. Es claro que principios como el de moralidad ${ }^{23}$, buena $\mathrm{fe}^{24}$, transparencia ${ }^{25}$, imparcialidad ${ }^{26}$,

intereses generales y actúa de acuerdo con los principios de eficacia, jerarquía, descentralización, desconcentración y coordinación, con sometimiento pleno a la ley y al derecho".

22 Por su parte, el artículo 3 de la Ley 1437 (2011), que constituye el Código de Procedimiento Administrativo y de lo Contencioso Administrativo, prevé los principios que corresponden a la función administrativa, incluye, en referencia particular a la ética pública, los principios de moralidad (rectitud, lealtad y honestidad), transparencia, buena fe, publicidad, igualdad, imparcialidad, responsabilidad, entre otros; y que la Ley 39 (2015) española de Procedimiento Administrativo establece para las actuaciones de las administraciones públicas.

${ }^{23}$ El artículo 23 de la Ley 80 (1993), que constituye el Estatuto de Contratación Pública de Colombia, contempla tales principios especiales de la contratación del Estado: "De Los Principios de las Actuaciones Contractuales de las Entidades Estatales. Las actuaciones de quienes intervengan en la contratación estatal se desarrollarán con arreglo a los principios de transparencia, economía y responsabilidad y de conformidad con los postulados que rigen la función administrativa. Igualmente, se aplicarán en las mismas las normas que regulan la conducta de los servidores públicos, las reglas de interpretación de la contratación, los principios generales del derecho y los particulares del derecho administrativo". Las regulaciones al respecto en el derecho español corresponden a la Ley 9 (2017).

24 La moralidad en el procedimiento administrativo la define el artículo 3 de la Ley 1437 (2011) de Colombia como: " 5 . En virtud del principio de moralidad, todas las personas y los servidores públicos están obligados a actuar con rectitud, lealtad y honestidad en las actuaciones administrativas".

25 Ley 1437 (2011) de Colombia: "4. En virtud del principio de buena fe, las autoridades y los particulares presumirán el comportamiento leal y fiel de unos y otros en el ejercicio de sus competencias, derechos y deberes".

26 El artículo 24 del Estatuto de Contratación Pública de Colombia de manera particular consagra el principio de transparencia, así: "Del principio de Transparencia. Reglamentado por el Decreto Nacional 287 de 1996. En virtud de este principio:

1o. Numeral Derogado por el art. 32 de la Ley 1150 de 2007. La escogencia del contratista se efectuará siempre a través de licitación o concurso público, salvo en los siguientes casos en los que se podrá contratar directamente...

20. En los procesos contractuales los interesados tendrán oportunidad de conocer y controvertir los informes, conceptos y decisiones que se rindan o adopten, para lo cual se establecerán etapas que permitan el conocimiento de dichas actuaciones y otorguen la posibilidad de expresar observaciones.

30. Las actuaciones de las autoridades serán públicas y los expedientes que las contengan estarán abiertos al público, permitiendo en el caso de licitación el ejercicio del derecho de que trata el artículo 273 de la Constitución Política.

4o. Las autoridades expedirán a costa de aquellas personas que demuestren interés legítimo, copia de las actuaciones y propuestas recibidas, respetando la reserva de que gocen legalmente las patentes, procedimientos y privilegios.

5o. En los pliegos de condiciones o términos de referencia:

a) Se indicarán los requisitos objetivos necesarios para participar en el correspondiente proceso de selección. Literal reglamentado por el Decreto Nacional 679 de 1994.

b) Se definirán reglas objetivas, justas, claras y completas que permitan la confección de ofrecimientos de la misma índole, aseguren una escogencia objetiva y eviten las declaratorias de desierta de la licitación o concurso. 
igualdad (Ley 1437, 2011, art. 3, num. 3), responsabilidad ${ }^{27}$, solo por mencionar algunos, buscan cumplir los criterios éticos que se deben acatar en el procedimiento administrativo de contratación. Por otra parte, las actuaciones de las autoridades administrativas que intervienen en los contratos públicos están obligadas a respetar con el fin de que se evidencie un proceder correcto que se ajuste a los conceptos de honestidad y rectitud.

Los principios de transparencia o de buena fe asisten significativamente el procedimiento de contratación en cada una de las etapas en que se desarrolla el mismo ${ }^{28}$, es decir, la precontractual, contractual y poscontractual, con las especificidades que corresponden a cada una de ellas teniendo en cuenta la participación de los servidores o autoridades públicas.

Es claro que los procederes éticos tienen que verse claramente determinados en cada una de las etapas del trámite de contratación. En la formación del contrato debe existir una clara, correcta y honesta actuación de las autoridades públicas que se evidencie en el principio de legalidad, el cual constituye una clara expresión de ética pública. En este sentido, las autoridades administrativas en la etapa precontractual actúan fundamentalmente a través de actos administrativos, a los cuales les corresponde como atributo la presunción de legalidad que se puede desvirtuar por violación de criterios éticos que determinen violación de la ley.

Cuando en la formación de la voluntad del contrato se viola un criterio o postulado ético, es decir, la Administración pública se aleja de la finalidad de "bien", generalmente se evidencia un acto administrativo ilegal, impugnable ante la jurisdicción de lo contencioso administrativo con fundamento en la existencia de una causal de nulidad que involucra vulneraciones éticas. Este hecho se puede evidenciar en los motivos de anulación de los actos administrativos previstos en los ordenamientos jurídicos colombianos y españoles, por ejemplo.

c) Se definirán con precisión las condiciones de costo y calidad de los bienes, obras o servicios necesarios para la ejecución del objeto del contrato.

d) No se incluirán condiciones y exigencias de imposible cumplimiento, ni exenciones de la responsabilidad derivada de los datos, informes y documentos que se suministren.

e) Se definirán reglas que no induzcan a error a los proponentes y contratistas y que impidan la Formulación de ofrecimientos de extensión ilimitada o que dependan de la voluntad exclusiva de la entidad.

f) Se definirá el plazo para la liquidación del contrato, cuando a ello hubiere lugar, teniendo en cuenta su objeto, naturaleza y cuantía.

Serán ineficaces de pleno derecho las estipulaciones de los pliegos o términos de referencia y de los contratos que contravengan lo dispuesto en este numeral, o dispongan renuncias a reclamaciones por la ocurrencia de los hechos aquí enunciados..."

27 El artículo 13 constitucional contempla el principio de igualdad en los siguientes términos: "Todas las personas nacen libres e iguales ante la ley, recibirán la misma protección y trato de las autoridades y gozarán de los mismos derechos, libertades y oportunidades sin ninguna discriminación por razones de sexo, raza, origen nacional o familiar, lengua, religión, opinión política o filosófica" (Constitución Política, 1991) .

28 La Ley 80 (1993) es explícita en contemplar el principio de responsabilidad en el artículo 26. 
En efecto, como la etapa precontractual implica fundamentalmente actuaciones unilaterales de la Administración que las realiza a través de actos administrativos, estos deben estar acordes al orden jurídico, no solamente en el sentido de la conformidad respecto de normas prevalentes desde un punto de vista formal, sino de principios y valores consagrados en las mismas, lo que implican necesariamente postulados éticos.

En el evento en que una entidad administrativa adjudica una licitación pública a un proponente $\mathrm{u}$ oferente que no cumple con los requisitos previstos en el pliego de condiciones ${ }^{29}$, se afectan criterios éticos porque la actuación de la autoridad del Estado puede estar contraviniendo principios como el de transparencia, imparcialidad, igualdad, buena fe. Estos principios, involucrados en el de legalidad, determinan una actuación totalmente alejada del buen servicio público, el interés general y, en últimas, del beneficio común que debe asistir al procedimiento administrativo.

De la misma manera ocurre en la etapa contractual ${ }^{30}$, en la que las regulaciones éticas han de estar a la orden del día, ya que los acuerdos entre las partes del contrato deben ejecutarse conforme a criterios de buena fe. Así, en el caso de existir actividades contrarias a la lealtad de quienes intervienen en el pacto, se puede presentar un incumplimiento del contrato con las debidas consecuencias indemnizatorias para la parte contraria. Este caso es, entonces, una clara muestra de vulneraciones del adecuado proceder público, si es que se derivan de la parte que representa al Estado.

Cuando una autoridad exige dineros a un contratista y este se niega a entregarlos, lo que da lugar a una persecución administrativa que culmina con la declaratoria de un incumplimiento alejado de la realidad y en el marco del abuso del poder público; se muestra la vulneración de postulados éticos que, en el plano del procedimiento de contratación, evidencia un incumplimiento por parte de la entidad del Estado, ya que viola un principio reconocido por la jurisprudencia y la doctrina en la denominación "de los deberes legales"31.

29 El Consejo de Estado de Colombia expresa en el Proceso 49847 (2016): "El principio de transparencia en la contratación estatal comprende aspectos tales como la claridad y la nitidez en la actuación contractual para poder hacer efectiva la supremacía del interés general, la libre concurrencia de los interesados en contratar con el Estado, la igualdad de los oferentes, la publicidad de todo el iter contractual, la selección objetiva del contratista, el derecho a cuestionar o controvertir las decisiones que en esta materia realice la Administración, etc.".

30 La Ley 1437 (2011), que constituye el Código de Procedimiento Administrativo, contempla las causales de nulidad de los actos administrativo en el artículo 137. En este especifica cada una de ellas, pero muestra que todas confluyen a la desviación o abuso del poder público, el cual constituye una clara vulneración de criterios éticos por parte de las autoridades administrativas. Para el caso español, estas están previstas en los artículos 47 y 48 de la Ley 39 (2015), Ley de Procedimiento Administrativo, los cuales hacen referencia a las causales de nulidad de pleno derecho y de anulabilidad de los actos administrativos.

31 En el derecho colombiano el pliego de condiciones es el documento administrativo que constituye la ley del contrato, como lo ha indicado el Consejo de Estado de Colombia en el Proceso 25642 (2013), cuando manifiesta: "En esa perspectiva, el pliego de condiciones constituye la ley tanto del procedimiento administrativo de selección del contratista, como del contrato a celebrar, razón por la que se traduce en un conjunto de disposiciones y cláusulas elaboradas unilateralmente por la administración, con efectos 
Las potestades públicas constituyen poderes unilaterales que se otorgan al Estado en los contratos que celebra como un mecanismo de actuación que le permite garantizar el interés general y la prestación adecuada de los servicios públicos. Pero estas prerrogativas tienen que ser utilizadas con criterios de rectitud, honestidad y, en términos éticos, de búsqueda del "bien" para la comunidad. Si se aleja de estos principios, muy posiblemente se presenta un incumplimiento del contrato que no solamente se da por violación del principio de los deberes legales, como ya se expresó, sino por vulneración de los acuerdos celebrados ${ }^{32}$.

En efecto, el incumplimiento de un contrato por parte de la entidad pública se presenta fundamentalmente por violación de dos principios: los deberes legales y la reciprocidad de prestaciones teniendo en cuenta los acuerdos entre las partes. En cuanto a lo que interesa del presente documento puede ser, en cualquier caso, por el desconocimiento de criterios éticos respecto de la vulneración de la ley o de los acuerdos celebrados.

Es claro que la violación del principio de los deberes legales y el de reciprocidad de prestaciones implica actividades irregulares de la Administración, es decir, alejadas de criterios éticos. Así, la violación de normas legales o lo pactado en el contrato es el resultado de la actuación de una autoridad pública que busca fines distintos al "bien" común, al beneficio social que se ha de evidenciar en el interés y el mejoramiento del servicio que debe asistir a todo el proceder de las entidades del Estado ${ }^{33}$.

Se trata, entonces, de una finalidad predeterminada por condicionamientos éticos. Los servidores públicos tienen la obligación de cumplir las regulaciones legales en el procedimiento de contratación en el sentido de los actos expedidos por el poder legislativo, además de las normas contractuales surgidas de los acuerdos celebrados que corresponden a los condicionamientos éticos de búsqueda del bien social. Por tal razón, cuando la persona jurídica del Estado se aleja de dichos condicionamientos, está vulnerando las regulaciones éticas que ha adoptado el grupo social.

obligatorios para ésta [sic| como para los proponentes u oferentes, en aras de disciplinar el desarrollo y las etapas del trámite de selección, como el contrato ofrecido a los interesados en participar en la convocatoria a través de la aspiración legítima de que éste [sic] les sea adjudicado para colaborar con aquélla en la realización de un fin general, todo lo cual ha de hacerse con plenas garantías y en igualdad de condiciones para los oferentes. Nota de relatoría: Sobre el tema consultar sentencia del Consejo de Estado, Sección Tercera, del 3 de mayo de 1999, exp. 12344".

32 En el derecho colombiano la etapa contractual va desde el perfeccionamiento del contrato, que en los términos del artículo 41 de la Ley 80 (1993) se da cuando hay acuerdo entre las partes y se eleva a escrito y transcurre hasta la liquidación del mismo.

33 Cuando una entidad pública utiliza un poder unilateral, como en el caso de la declaratoria de incumplimiento de un contrato, debe hacerlo acorde con las exigencias o deberes previstos en las normas legales, como mecanismo de garantía de derechos de los particulares que intervienen en los contratos públicos. De esta manera, muestran el criterio de igualdad que ha de existir entre las partes que se involucran en los acuerdos. Pero si una persona jurídica pública se aleja de dichos deberes o exigencias, incurre en un incumplimiento del contrato precisamente por violación del principio de los deberes legales, lo que puede ser una clara vulneración de criterios éticos, que es lo que no interesa desarrollar en este escrito. 
Se debe aclarar que los postulados éticos en la contratación pública deben asistir a todas las actuaciones de las autoridades administrativas en cualquiera de las etapas del procedimiento de contratación, sin importar el mecanismo a través del cual se instrumentalicen. En este sentido, se puede tratar de un acto administrativo, una omisión o el contrato como tal. Este hecho permite afirmar que no importa el mecanismo de proceder del servidor público, debe estar asistido de principios éticos y por tal razón de legalidad, ya que no es otra la consecuencia de la misma.

La legalidad de un acto conlleva por regla general una concordancia con postulados éticos, lo que implica su identificación con el concepto de "bien" o beneficio social, así como respeto por el interés general en las actuaciones administrativas. Esta circunstancia nos permite afirmar que la ilegalidad de un acto administrativo conlleva necesariamente la vulneración de regulaciones éticas.

Podría pensarse que esta argumentación contraría criterios jurídicos de legalidad o de ilegalidad y, por ende, de anulación de actos administrativos, ya que cuando se verifica la legalidad de un acto, en este caso dentro del procedimiento de contratación, lo único que se hace, en muchas ocasiones, es compararlo con una norma jurídica prevalente sin ningún interés por los contenidos éticos de la misma. Pero esto no es cierto porque tanto en la actuación de la Administración inmersa en el acto como en la norma de referencia existen contendidos éticos, ya que la noción de "bien" o beneficio social determina la actividad de la Administración como del legislador.

No es otra la sustentación que se debe hacer en este caso porque cuando el Parlamento expide una norma en relación con el procedimiento de contratación, lo hace respetando criterios éticos. Pero, a su vez, cuando un servidor público actúa, desarrolla una actividad en un trámite de contratos públicos y se ajusta a la norma superior, respeta la materialidad ética de esta y su proceder es igualmente ético. Por el contrario, cuando se contraría la regulación normativa de prevalencia, los principios éticos se están viendo afectados.

Es cierto que alguna doctrina indica que una actuación en un procedimiento de contratación pública puede ser legal, pero no ético. Tal sería el caso de la adición de un contrato estatal estando suspendido por la jurisdicción de lo contencioso administrativo en el trámite de una acción judicial y, sin embargo, las partes se ponen de acuerdo para incrementar su valor agregando otras actividades al objeto del mismo ${ }^{34}$.

34 La Corte Constitucional de Colombia en Sentencia C-713 (2009) sobre el interés general en los contratos públicos ha dicho: "El fin de la contratación pública en el Estado Social de Derecho está directamente asociado al cumplimiento del interés general, puesto que el contrato público es uno de aquellos "instrumentos jurídicos de los que se vale el Estado para cumplir sus finalidades, hacer efectivos los deberes públicos y prestar los servicios a su cargo, con la colaboración de los particulares a quienes corresponde ejecutar, a nombre de la administración, las tareas acordadas. El interés general, además de guiar y explicar la manera como el legislador está llamado a regular el régimen de contratación administrativa, determina las actuaciones de la Administración, de los servidores que la representan y de los contratistas, 
En este caso se ha dicho que la adición es legal porque se debe distinguir la existencia del contrato de sus efectos. Así, como el contrato no ha salido de la vida jurídica, es posible adicionarlo aunque esté suspendido. Pero lo que sucede es que la adición corre la misma suerte del contrato principal, lo que significa que no surte efectos, por lo que la legalidad no se vería afectada. Se visualiza así que no parece ser ético adicionar un contrato suspendido porque la suspensión implica existencia de violación de normas jurídicas superiores, es decir, de ilegalidad. Esta argumentación nos parece incorrecta, ya que consideramos que si la adición es legal, la actuación del servidor público es igualmente ética.

Si la adición para el caso planteado es acorde con el ordenamiento jurídico, también se estarían respetando los principios de regulación ética, ya que las normas contienen en sí mismas fundamentaciones de tal naturaleza. En este sentido, la legalidad implica ajustarse a la materialidad de las normas jurídicas que conllevan las regulaciones preestablecidas de la noción de "bien" para el grupo social en el cual son adoptadas y realizadas. De esta manera, existe una coincidencia entre lo legal y lo ético, por lo que no es posible afirmar que se actúa legalmente mientras se vulneran criterios de proceder recto en la función administrativa o, al contrario, que existió una actividad alejada de la legalidad que se ajusta a la noción de "bien"35.

estos últimos vinculados al cumplimiento de las obligaciones generales de todo contrato y por ende supeditados al cumplimiento de los fines del Estado".

35 En el campo de la función administrativa, entre las cuales está la actividad de contratación, los condicionamientos éticos son referidos o expresados a través de la denominada moralidad administrativa, como lo hace el Consejo de Estado de Colombia en el Expediente 2005-01330-01 (2015) cuando expresa: "Resulta importante señalar que a la luz de la Constitución Política, la moralidad administrativa ostenta naturaleza dual. En efecto, funge como principio de la función administrativa (Constitución Política, artículo 209 y ley 489 de 1998, artículo 3) y como derecho colectivo. En el primer caso, esto es como principio, orienta la producción normativa infra-constitucional e infra-legal a la vez que se configura como precepto interpretativo de obligatoria referencia para el operador jurídico; y como derecho o interés colectivo, alcanza una connotación subjetiva, toda vez que crea expectativas en la comunidad susceptibles de ser protegidas a través de la acción popular, y así lo ha reconocido esta corporación en fallos anteriores. Así las cosas, la jurisprudencia constitucional y contencioso administrativa ha señalado que el derecho colectivo a la moralidad administrativa puede resultar vulnerado o amenazado cuando se verifiquen varios supuestos. En primer lugar, resulta necesario que se pruebe la existencia de unos bienes jurídicos afectados y su real afectación. Al entender de esta Sala dichos bienes jurídicos comprenderían la buena fe, la ética, la honestidad, la satisfacción del interés general, la negación de la corrupción, entre otros; y habrá lugar a que se configure de forma real su afectación, si se prueba el acaecimiento de una acción u omisión, de quienes ejercen funciones administrativas, con capacidad para producir una vulneración o amenaza de dichos bienes jurídicos, que se genera a causa del desconocimiento de ciertos parámetros éticos y morales sobre los cuales los asociados asienten en su aplicación". Al respecto, la Corte Constitucional ha establecido que la moralidad administrativa no se predica únicamente del "fuero interno de los servidores públicos sino que abarca toda la gama del comportamiento que la sociedad en un momento dado espera de quienes manejan los recursos de la comunidad y que no puede ser otro que el de absoluta pulcritud y honestidad". En segundo término, la jurisprudencia constitucional y contencioso administrativa han reiterado que la vulneración a la moralidad administrativa supone generalmente el quebrantamiento del principio de legalidad. Por último, la jurisprudencia ha reiterado que la vulneración de la moralidad administrativa 
Parecería una tautología, pero no se puede argumentar de otra manera en el sentido de identificar la legalidad inmersa en la ética, porque no concebimos un ordenamiento jurídico alejado de criterios encaminados al beneficio general. Así, en un Estado de derecho, y en especial en un Estado social de derecho, el sistema normativo corresponde a regulaciones éticas, lo que significa que la legalidad se involucra en los criterios éticos, así la ética no se agote en la legalidad ${ }^{36}$.

De esta manera, la ética tiene que influir necesariamente en el procedimiento administrativo de contratación, en la medida que las autoridades públicas están obligadas a acatar los principios de buen actuar que han sido reconocidos por el medio social y que se incluyen en el ordenamiento jurídico. En el caso colombiano esto sucede cuando se hace referencia a la necesidad de respetar el interés colectivo de la moralidad administrativa en la contratación pública donde se exige que, para la vulneración de dicho interés colectivo, se ha debido violar una norma legal ${ }^{37}$.

Como se puede observar, la ética pública determina, de una u otra forma, el procedimiento de contratación del Estado. Ahora bien, falta ver qué sucede cuando una autoridad pública viola los principios éticos y si se genera algún tipo de responsabilidad administrativa.

coincide con "el propósito particular que desvíe el cumplimiento del interés general al favorecimiento del propio servidor público o de un tercero". Sin duda, esta noción se acerca a la desviación de poder.

36 Así lo plantea el Consejo de Estado de Colombia en la Radicación 66001233100020100034301 (2015): "En criterio de la Sala, la moralidad administrativa es un valor constitucional que, si bien lo contiene, alcanza mayor jerarquía que el de legalidad, en tanto no se agota en éste [sic], trasciende a valores que la sociedad reclama de la administración así no estén expresamente previstos en las normas y reglamentos, para el efecto la diligencia, prudencia, pulcritud, honestidad, rectitud, seriedad y ponderación en lo discrecional, racionalidad del juicio, respeto y lealtad, en el manejo de lo que interesa a todos". Esta argumentación implica que la ética, en su referencia a la moralidad administrativa, es decir, en procura del bien común, contiene la legalidad, y la vulneración de esta implica la violación de la primera. De la misma forma, si una actuación se ajusta a la legalidad, se ajusta a la ética o a la moralidad administrativa.

37 El Consejo de Estado de Colombia en el Expediente 25000-23-26-000-2003-02458-01(AP) (2005), así lo determina cuando dice: "Teniendo en cuenta el carácter básicamente legislado del Derecho Colombiano, el estudio que debe efectuarse sobre la moralidad administrativa en las acciones populares no está encaminado a hacer un juicio volitivo o de conciencia sobre la actuación del funcionario o del Estado, pues lo perseguido a través de esta acción es la protección del derecho a la moralidad administrativa, donde la evaluación de la conducta de la autoridad sólo [sic| puede hacerse bajo la perspectiva de la función administrativa, enmarcada por los principios constitucionales y las normas jurídicas. Y entonces para que pueda hablarse de vulneración a tal derecho colectivo, debe existir necesariamente una trasgresión al ordenamiento jurídico además de otros elementos adicionales, porque no toda ilegalidad atenta contra dicho derecho, debiendo probarse también la mala fe de la Administración y la vulneración a otros derechos colectivos. En efecto, cuando la moral como regulador de la conducta del ser humano, entendida como aquellos valores imperantes en un espacio y época determinada y que en principio carecen de poder de coercibilidad frente a quien las infringe, son retomadas por el derecho para convertirlas en normas positivas de obligatorio acatamiento, su incumplimiento unido a otros requisitos adicionales como la desnaturalización de la función pública ejecutada, la corrupción para desembocar en la satisfacción de intereses particulares etc., puede conducir al agravio del derecho colectivo a la moral administrativa. Nota de relatoría: ver exp. AP-163 del 6 de septiembre de 2001". 


\section{LA RESPONSABILIDAD CONTRACTUAL DEL ESTADO: VIOLACIÓN DE LA ÉTICA PÚBLICA}

La responsabilidad de la Administración pública, derivada del procedimiento de contratación, está prevista en el artículo 90 constitucional que es el fundamento de toda la responsabilidad del Estado en el sistema jurídico colombiano ${ }^{38}$, así como en los artículos 26 y 50 de la Ley 80 (1993) que constituye el Estatuto de Contratación Público de Colombia ${ }^{39}$.

En el derecho colombiano, toda la responsabilidad del Estado, bien sea extracontractual o contractual, gira en torno a la existencia de un daño antijurídico en el sentido de que quien lo sufre no esté obligado a soportarlo ${ }^{40}$, ya que se ha vulnerado el principio de igualdad frente las cargas públicas. Pero en el caso de la responsabilidad contractual se presenta una exigencia adicional en el sentido de que la actuación también tiene que ser antijurídica, lo cual no ocurre en el caso de la responsabilidad extracontractual.

En efecto, cuando el artículo 50 de la Ley 80 (1993), correspondiente a los contratos públicos, expresa que las entidades públicas responderán por las actuaciones, abstenciones, hechos y omisiones antijurídicas que le sean imputables, se muestra que la antijuridicidad que se debe presentar en el daño, según lo previsto en el artículo 90, también debe aparecer en la actuación debido a que se consigna como una exigencia de esta.

En consecuencia, para que en el sistema jurídico colombiano exista responsabilidad contractual del Estado, es necesario que tanto la actuación como el daño sean antijurídicos, lo que nos lleva a la existencia de una responsabilidad por falla del servicio. De esta manera, la responsabilidad en los contratos públicos se aleja de los criterios objetivos que han caracterizado la obligación de indemnizar perjuicios.

Como el presente escrito está encaminado a verificar la responsabilidad contractual del Estado por violaciones a la ética pública, es preciso concentrarnos en las actuacio-

38 El artículo 90 constitucional dice: "El Estado responderá patrimonialmente por los daños antijurídicos que le sean imputables, causados por la acción o la omisión de las autoridades públicas. En el evento de ser condenado el Estado a la reparación patrimonial de uno de tales daños, que haya sido consecuencia de la conducta dolosa o gravemente culposa de un agente suyo, aquél deberá repetir contra éste [sic]" (Constitución Política, 1991).

39 El artículo 26 de la Ley 80 (1993) contempla el principio de responsabilidad en los contratos del Estado. En este sentido, hace especial referencia a las obligaciones de quienes participan en dicho procedimiento administrativo. Pero la responsabilidad del Estado, como consecuencia de los daños causados en los contratos públicos, está prevista de manera particular en el artículo 50 de la Ley 80 (1993) que dice: "De la responsabilidad de las entidades estatales. Las entidades responderán por las actuaciones, abstenciones, hechos y omisiones antijurídicos que les sean imputables y que causen perjuicios a sus contratistas. En tales casos deberán indemnizar la disminución patrimonial que se ocasione, la prolongación de la misma y la ganancia, beneficio o provecho dejados de percibir por el contratista".

40 Ver el Expediente 0500123250001994227901 (2012) y el Proceso 19976 (2011) del Consejo de Estado de Colombia, 
nes de las autoridades administrativas. En este sentido, se parte del supuesto de que estas tendrán que ser antijurídicas, es decir, irregulares en criterios de responsabilidad del Estado, los cuales además involucran la ilegalidad de ellas.

Es claro que cuando una actuación administrativa es antijurídica, la autoridad pública está incurriendo en un proceder alejado de buen servicio público, esto es, está desprovisto de criterios de interés general o actúa de manera ilegal en tanto incurre en violaciones de normativas en sentido genérico. Este hecho no puede significar otra cosa que la antijuridicidad en la actuación ${ }^{41}$ que, de una u otra forma, implica una actividad irregular por parte de la Administración pública ${ }^{42}$.

Si nos enfrentamos a actuaciones irregulares cuando hablamos de antijuridicidad, es preciso verificar de manera concreta en qué eventos se presentan en el procedimiento de contratación pública como exigencia para que se configure la responsabilidad del Estado. De la misma manera, es importante evaluar si estas implican, de alguna forma, violaciones a la ética pública.

En dichas circunstancias, la responsabilidad administrativa contractual se deriva fundamentalmente del incumplimiento del contrato por parte de las entidades públicas, ya que esta es la forma más clara de evidenciar una actuación antijurídica o irregular por parte de la Administración en esta etapa del procedimiento administrativo de contratación ${ }^{43}$. Este incumplimiento implica, entonces, la vulneración de normas legales o la sustracción a los acuerdos pactados.

Cuando una entidad pública hace un uso indebido de una potestad excepcional, como podría ser la declaratoria de caducidad en el entendido de la terminación del contrato por incumplimiento del contratista ${ }^{44}$, está en la obligación de cumplir

41 Las actuaciones irregulares de las autoridades administrativas las debo identificar con la falla del servicio. En este sentido, es conveniente traer a colación el fallo Pelletier del Tribunal de Conflictos Francés de 1873 que, en mi concepto, fue el primero que se refirió a la responsabilidad del Estado por actuaciones antijurídicas. En este contexto, Long et al. (2017) afirman: "Selon la conception de l’arrêt Pelletier, la faute personnelle est celle qui se détache assez complètement du service pour que le juge judiciaire puisse en faire la constatation sans porter pour autant une appréciation sur la marche même de l'administration. La faute de service au contraire est tellement liée au service que son appréciation par le juge judiciaire implique nécessairement une appréciation sur le fonctionnement du service" (p. 10). Lo anterior implica, para el asunto que me ocupa, que la idea de servicio público tiene que estar ligada a la actuación de la autoridad administrativa en ejercicio, con ocasión o movida por el mismo, para que se pueda configurar la responsabilidad del Estado en el criterio que posteriormente consignaría Paul Due.

42 Sobre actuaciones irregulares o antijurídicas que constituyen falla del servicio ver, por ejemplo, el Proceso 29334 (2016) del Consejo de Estado de Colombia.

43 El incumplimiento del contrato por parte de la Administración se deriva de la violación de dos principios fundamentales que han sido reconocidos por la doctrina como son: el de los deberes legales y el de reciprocidad de prestaciones, es decir, de los acuerdos celebrados entre las partes.

${ }^{44}$ Ver artículo 18 de la Ley 80 (1993) que expresa: "De la caducidad y sus efectos. La caducidad es la estipulación en virtud de la cual si se presenta alguno de los hechos constitutivos de incumplimiento de las obligaciones a cargo del contratista, que afecte de manera grave y directa la ejecución del contrato y evidencia que puede conducir a su paralización, la entidad por medio de acto administrativo 
un cúmulo de normas jurídicas que garanticen el debido proceso y el derecho de defensa del contratista ${ }^{45}$. Pero si por alguna circunstancia se aleja de dicho cumplimiento, estaría violando las disposiciones legales y vulneraría así el principio de los deberes legales, con lo que incumpliría el contrato ${ }^{46}$.

De otra parte, en caso de que se rompa el equilibrio económico del contrato ${ }^{47}$, la parte pública contratante está en la obligación de restablecerlo en tanto se den los requisitos para ello. Pero si se sustrae de manera injustificada a dicho restablecimiento, está incurriendo en un incumplimiento del contrato por violación del principio de los deberes legales. Este hecho constituye una actuación irregular, es decir, antijurídica porque existe una violación normativa por parte de la autoridad administrativa al sustraerse del mandato legal ${ }^{48}$.

En cualquiera de los dos casos mencionados, existe un proceder de la Administración alejado del buen servicio público de cumplimiento del interés general y específicamente del principio de legalidad, lo que implica que se está incurriendo en violaciones de la ética pública. Esto se debe a que al vulnerarse dichos criterios, como lo expresamos en los acápites uno y dos que antecedieron, la actuación administrativa se aleja de la noción de "bien" al cual debe propender la función administrativa.

En efecto, no es lógico afirmar que una actuación contraria a la legalidad, el buen servicio o el interés general, se ajusta a criterios de ética pública. Por el contrario,

debidamente motivado lo dará por terminado y ordenará su liquidación en el estado en que se encuentre. En caso de que la entidad decida abstenerse de declarar la caducidad, adoptará las medidas de control e intervención necesarias, que garanticen la ejecución del objeto contratado. La declaratoria de caducidad no impedirá que la entidad contratante tome posesión de la obra o continúe inmediatamente la ejecución del objeto contratado, bien sea a través del garante o de otro contratista, a quien a su vez se le podrá declarar la caducidad, cuando a ello hubiere lugar. Si se declara la caducidad no habrá lugar a indemnización para el contratista, quien se hará acreedor a las sanciones e inhabilidades previstas en esta ley. La declaratoria de caducidad será constitutiva del siniestro de incumplimiento".

45 El artículo 86 de la Ley 1474 (2011), que constituye el Estatuto Anticorrupción de Colombia, consagra el trámite del procedimiento sancionatorio en asuntos contractuales que debe ser necesariamente aplicado cuando se va a declararla caducidad de un contrato.

46 Es un deber legal la utilización debida o adecuada de las potestades excepcionales. Por tal razón, si la entidad pública utiliza de forma indebida tales prerrogativas, entonces incumple el contrato.

47 El artículo 27 de la Ley 80 (1993) contempla el principio del equilibrio económico del contrato así: "De la ecuación contractual. En los contratos estatales se mantendrá la igualdad o equivalencia entre derechos y obligaciones surgidos al momento de proponer o de contratar, según el caso. Si dicha igualdad o equivalencia se rompe por causas no imputables a quien resulte afectado, las partes adoptarán en el menor tiempo posible las medidas necesarias para su restablecimiento. Para tales efectos, las partes suscribirán los acuerdos y pactos necesarios sobre cuantías, condiciones y forma de pago de gastos adicionales, reconocimiento de costos financieros e intereses, si a ello hubiere lugar, ajustando la cancelación a las disponibilidades de la apropiación de que trata el numeral 14 del artículo 25. En todo caso, las entidades deberán adoptar las medidas necesarias que aseguren la efectividad de estos pagos y reconocimientos al contratista en la misma o en la siguiente vigencia de que se trate".

48 Sobre el rompimiento del equilibrio económico del contrato, ver el Expediente 1998-03066-01 (2014) del Consejo de Estado de Colombia,. 
es una forma clara de su vulneración, en la medida en que el beneficio general se ve evidentemente afectado con la actividad de las autoridades administrativas.

De la misma forma, en caso de que una entidad pública se sustraiga de los acuerdos pactados en el contrato, como podría ser que incurra en mora en los pagos o entregue estudios o diseños equivocados, está violando el principio de reciprocidad de prestaciones. En estas circunstancias, se presenta un incumplimiento del contrato que refleja las actuaciones irregulares de la Administración, las cuales se tornan antijurídicas y generan responsabilidad contractual en tanto dan lugar a un daño igualmente antijurídico ${ }^{49}$.

Estas actuaciones muestran una clara violación de la ética pública que dan lugar a la existencia de una responsabilidad administrativa contractual, en el sentido de que se deben reparar los daños o perjuicios causados a la parte contraria contratista. De esta manera, se genera una sanción para la Administración por transgredir los principios y postulados del buen actuar en el ejercicio de la función administrativa.

La responsabilidad contractual constituye, en tales circunstancias, un mecanismo sancionatorio para la Administración ${ }^{50}$ en los eventos en que ha causado daños a los contratistas con sus actuaciones antijurídicas, lo que determina una obligación de reparación para sanear el incorrecto proceder dentro del procedimiento administrativo de contratación ${ }^{51}$.

Lo anterior significa que la violación a la ética pública en los contratos del Estado, que da lugar a la responsabilidad contractual, se deriva de las actuaciones que por regla general causan daños antijurídicos e indemnizables. Estas actuaciones corresponden,

49 Cuando la entidad pública incumple los acuerdos del contrato surge una responsabilidad administrativa contractual declarada por el juez de lo contencioso administrativo. Pero cuando lo hace el contratista es posible declarar la caducidad del contrato por parte de la persona jurídica contratante, como lo expresa el Consejo de Estado de Colombia mediante el Proceso 24697 (2013).

50 Sobre la responsabilidad contractual del Estado y sus elementos, el Proceso 18499 (2010) del Consejo de Estado de Colombia expresa: "Y en relación con el concepto de Responsabilidad Contractual, la Sala explicó lo siguiente en sentencia proferida el 25 de febrero de 2009, expediente 16.103: "Para resolver el caso que ahora se examina resulta necesario precisar el concepto de la responsabilidad contractual de la Administración Pública, según el cual las entidades públicas están obligadas a indemnizar a sus contratistas por los daños antijurídicos que les sean causados con ocasión de los contratos celebrados con las mismas entidades". Y en Consejo de Estado de Colombia, Proceso 17552 de 2009, explicó el concepto de responsabilidad contractual por incumplimiento así: "Ahora bien, sabido es que existe responsabilidad contractual sólo [sic] a condición de que cualquiera de las partes deje de ejecutar por su culpa el contrato y haya causado un perjuicio al acreedor. Para que se estructure esa responsabilidad contractual por infracción a la ley del contrato, debe demostrarse: (i) el incumplimiento del deber u obligación contractual, bien porque no se ejecutó o lo fue parcialmente o en forma defectuosa o tardía; (ii) que ese incumplimiento produjo un daño o lesión al patrimonio de la parte que exige esa responsabilidad y, obviamente, (iii) que existe un nexo de causalidad entre el daño y el incumplimiento".

51 La reparación implica una protección del patrimonio del contratista que se ve afectado con la actuación administrativa por la parte contratante en el acuerdo celebrado. En esta medida, surge un interés en la reparación que implica que el patrimonio afectado se coloque en las condiciones en que se encontraba antes de la actuación antijurídica de la entidad pública en el contrato. 
en sentido estricto, al incumplimiento del contrato por las entidades estatales, lo que genera una obligación de reparación de las afectaciones patrimoniales causadas.

Pero dichas actuaciones por regla general, aunque constituyen violaciones a la ética pública, al contrario de lo que podría pensarse, no siempre constituyen procederes corruptos por parte de las autoridades públicas, aunque en algunos casos sí es posible evidenciarlo. En este sentido, pretendemos afirmar que la violación de la ética pública en el procedimiento de contratación puede provenir o no de actos de corrupción $n^{52}$. Sin embargo, si existe incumplimiento del contrato, entonces se presentan vulneraciones al correcto proceder de las autoridades administrativas y, en estas circunstancias, siempre se vulnera la ética pública.

Parece no ser fácil la anterior argumentación porque se ha creído que en la vulneración de la ética pública siempre están presentes actos de corrupción y, en alguna medida, actuaciones delictuales. Pero, según mi criterio, esto no es cierto, ya que la violación de los principios éticos (al menos en la contratación del Estado) no se agota con los actos de corrupción. Antes bien, en algunos casos y específicamente en la responsabilidad derivada del incumplimiento del contrato, puede que en estricto sentido no haya un acto de corrupción aunque se puede estar violando dicha ética pública.

Lo anterior implica que siempre que exista un incumplimiento del contrato y, en tal medida, una responsabilidad contractual, se presenta violación de los principios éticos porque el proceder de las autoridades administrativas está contrariando el buen actuar de la Administración que se debe encaminar al cumplimiento de los fines del Estado y al acatamiento de los principios de la función administrativa. Estos principios se trasgreden cuando no se cumple el contrato por parte de la entidad pública que es partícipe en este y se genera la obligación de reparar los daños antijurídicos que se causen, es decir, se da una responsabilidad administrativa del Estado.

Dicha prescripción se sustenta, además, a través de los títulos de imputación de responsabilidad que la doctrina y la jurisprudencia han adoptado para la etapa contractual del procedimiento de contratación. Dentro de estos, se encuentra la violación del principio de buena fe ${ }^{53}$ que implica la obligación de las partes en el contrato. En

52 Respecto a la responsabilidad del Estado por actos de corrupción, ver Guerra (2007).

53 Sobre la imputación contractual, el Proceso 18499 (2010) del Consejo de Estado de Colombia dice al respecto: "La imputación del daño a la entidad contratante. La imputación que permite atribuir el daño a un sujeto de derecho comporta un juicio jurídico que involucra una valoración de la causa material del mismo y del título de imputación aplicable al caso concreto. La responsabilidad contractual puede ser subjetiva, cuando el juicio de imputación se edifica en el incumplimiento del contrato estatal conforme lo precisó la Sala, entre otras, en sentencia proferida 25 de febrero de 2009, 'El incumplimiento contractual puede revestir tres formas: la mora o falta de cumplimiento de la obligación en el plazo estipulado; el cumplimiento defectuoso de la obligación '( ) cuando la conducta se dirige a ejecutar la prestación que constituye el objeto de la obligación, pero no se logra la extinción de ésta [sic], porque la ejecución de la obligación no se ajusta a los parámetros y condiciones exigidas por el contrato, la ley, o la buena fe para la satisfacción 
este caso, la entidad pública debe actuar con lealtad y transparencia en la ejecución del acuerdo celebrado ${ }^{54}$ que, en nuestra consideración, se aleja de tales prescripciones cuando la Administración incumple los contratos en que es parte.

Debemos indicarlo de dicha manera porque si una entidad del Estado incumple un contrato, entonces su conducta es antijurídica e irregular, lo que significa que se aleja de un actuar ajustado a un buen servicio público o en cumplimiento del interés general. Estos incumplimientos demuestran que el accionar no está ajustado a la transparencia o a la lealtad en la ejecución de los acuerdos celebrados, lo que significa una clara violación al principio de buena fe y, por ende, a la ética pública ${ }^{55}$.

Asimismo, se viola la ética pública porque se afecta la noción de "bien" en la actuación por parte de la persona jurídica del Estado que incumple lo previsto en el contrato que, como lo indicamos anteriormente, debe encaminarse al beneficio general o a lo que alguna doctrina ha denominado el bien común, ya que como la actuación es antijurídica, esto es, existe una irregularidad en la misma que altera los criterios de lealtad de las apartes en el contrato.

del interés público' y el incumplimiento definitivo de la obligación que la doctrina encuadra dentro de tres situaciones: i) por 'la imposibilidad sobrevenida de la prestación objetiva y absoluta'; ii) 'la imposibilidad relativa por expiración del plazo contractual con frustración del fin de interés público del contrato' y iii) por, 'la decisión inequívoca de la Administración de no ejecutar el objeto contractual' Como también en sentencia proferida el 23 de abril de 2008: 'siendo principio general el que los contratos se celebran para ser cumplidos y, como consecuencia, que las partes deban ejecutar las obligaciones que emanan de él en forma íntegra, efectiva y oportuna, el incumplimiento de las mismas, esto es, su falta de ejecución o su ejecución tardía o defectuosa, es sancionada por el orden jurídico a título de responsabilidad subjetiva y por culpa".

54 La Corte Constitucional de Colombia ha identificado el principio de buena fe en la contratación pública cuando afirmó en la Sentencia T-209 (2006): "En relación a la existencia y aplicación del principio de buena fe dentro del régimen colombiano de contratación estatal, es oportuno destacar que a partir del fundamento constitucional al que se ha hecho mención, el mismo aparece expresamente contenido en el artículo 28 del Estatuto General de Contratación de la Administración Pública -Ley 80 de 1993, que, al hacer referencia a los criterios de interpretación de las reglas contractuales, dispone: 'En la interpretación de las normas sobre contratos estatales, relativas a procedimientos de selección y escogencia de contratistas y en la de las cláusulas y estipulaciones de los contratos, se tendrá en consideración los fines y los principios de que trata esta ley, los mandatos de la buena fe y la igualdad y equilibrio entre prestaciones y derechos que caracteriza a los contratos conmutativos'. El valor ético de la confianza como fundamento del contrato administrativo adquiere relevancia particular porque contribuye a humanizar las relaciones entre la Administración y el administrado. Dada la supremacía jurídica de la Administración Pública es necesario que su conducta se someta a los dictados éticos de la buena fe; por ejemplo, en los contratos administrativos, que es el objeto de esta tutela, en los que el derecho le confiere a la Administración una posición de potentior personae, que se manifiesta no sólo [sic] en la atribución de las potestades de modificarlo, terminarlo o interpretarlo mediante el ejercicio de la decisión unilateral y ejecutoria, sino también en otros poderes y privilegios, tales como el de control y dirección, el de imponer sanciones, etc.".

55 El principio de buena fe tiene un rango constitucional en el sistema jurídico colombiano, como lo prevé el artículo 83 que dice: "Las actuaciones de los particulares y de las autoridades públicas deberán ceñirse a los postulados de la buena fe, la cual se presumirá en todas las gestiones que aquellos adelanten ante éstas [sicl" (Constitución Política, 1991). 
Consideramos que existe coincidencia entre el incumplimiento del contrato, la violación del principio de buena fe, la vulneración de la ética pública y, por ende, la existencia de responsabilidad contractual del Estado. Esta responsabilidad no es más que un mecanismo de sanción a la Administración por violación de tales postulados.

Esta argumentación se sustenta en la obligación de reparar los daños causados que, en el criterio de la jurisprudencia y la doctrina, no es más que una sanción para la Administración. En este sentido, debe proteger el patrimonio del contratista y llevarlo a un plano de igualdad al que se encontraba al momento de surtirse la actuación administrativa que dio lugar a la afectación patrimonial ${ }^{56}$, lo cual es plenamente reconocido en la responsabilidad en el procedimiento de contratación fundamentado en el Estatuto de Contratación Público de Colombia.

La Ley 80 (1993) establece eventos puntuales en los que es obligación indemnizar plenamente al contratista por actuaciones derivadas del incumplimiento de los contratos, como es el caso de las referencias que hace al derecho que tiene para que se le restablezca el equilibrio económic ${ }^{57}$ y a la utilización de las cláusulas excepcionales ${ }^{58}$.

En síntesis, consideramos que la responsabilidad contractual constituye un mecanismo sancionatorio por violación de la ética pública, fundamentalmente en los eventos de incumplimiento del contrato, por existir una actuación antijurídica aunque se esté o no frente a actos de corrupción.

56 El criterio que la indemnización implica una sanción para la Administración conlleva a la reparación integral de los perjuicios causados, como lo ha previsto la jurisprudencia francesa en diversos casos, que se puede evidenciar en fallos como el Deberes del Consejo de Estado Francés de 7 de abril de 1933 por ejemplo.

57 El Artículo 5 de la Ley 80 (1993) establece en el numeral primero: "De los derechos y deberes de los contratistas. Para la realización de los fines de que trata el artículo 3o. de esta Ley, los contratistas: 1. Tendrán derecho a recibir oportunamente la remuneración pactada y a que el valor intrínseco de la misma no se altere o modifique durante la vigencia del contrato. En consecuencia tendrán derecho, previa solicitud, a que la administración les restablezca el equilibrio de la ecuación económica del contrato a un punto de no pérdida por la ocurrencia de situaciones imprevistas que no sean imputables a los contratistas. Si dicho equilibrio se rompe por incumplimiento de la entidad estatal contratante, tendrá que restablecerse la ecuación surgida al momento del nacimiento del contrato".

58 Por su parte el artículo 14 de la Ley 80 (1993) contempla: "De los medios que pueden utilizar las entidades estatales para el cumplimiento del objeto contractual. Para el cumplimiento de los fines de la contratación, las entidades estatales al celebrar un contrato: 1. Tendrán la dirección general y la responsabilidad de ejercer el control y vigilancia de la ejecución del contrato. En consecuencia, con el exclusivo objeto de evitar la paralización o la afectación grave de los servicios públicos a su cargo y asegurar la inmediata, continua y adecuada prestación, podrán en los casos previstos en el numeral 2 de este artículo, interpretar los documentos contractuales y las estipulaciones en ellos convenidas, introducir modificaciones a lo contratado y, cuando las condiciones particulares de la prestación así lo exijan, terminar unilateralmente el contrato celebrado. En los actos en que se ejerciten algunas de estas potestades excepcionales deberá procederse al reconocimiento y orden de pago de las compensaciones e indemnizaciones a que tengan derecho las personas objeto de tales medidas y se aplicarán los mecanismos de ajuste de las condiciones y términos contractuales a que haya lugar, todo ello con el fin de mantener la ecuación o equilibrio inicial". 


\section{CONCLUSIONES}

La ética consiste en actuaciones encaminadas al "bien", primero en interés particular y luego del grupo social.

La noción de "bien" se identifica con beneficio, es decir, lo que favorezca tanto al individuo como a la comunidad, en la medida en que se desarrolla en las relaciones interpersonales.

Los criterios de buen servicio público, interés general y principio de legalidad determinan la noción de bien y ética pública en el marco de actuación de las autoridades administrativas.

La contratación pública constituye un mecanismo de actuación del Estado que se desarrolla a través del ejercicio de función administrativa, por lo que se le aplican los principios constitucionales y legales que la rigen.

Si la contratación del Estado es función administrativa y se le aplican los principios de la misma, la ética pública está inmersa en todas y cada una de las actuaciones que se deben desarrollan en la contratación estatal.

Una de las formas más claras de violar la ética pública en la contratación del Estado es el incumplimiento de los acuerdos celebrados, así como el ejercicio de actuaciones que violan los deberes y obligaciones previstos en la ley.

Siempre que se hable de responsabilidad contractual del Estado, se han presentado violaciones a la ética pública.

La responsabilidad contractual del Estado está fundada en violaciones de la ética pública y, por dicha razón, constituiría el único título de atribución de responsabilidad administrativa en la etapa contractual dentro del procedimiento de contratación.

La responsabilidad contractual se deriva de actuaciones irregulares de las autoridades administrativas, teniendo en cuenta que el Estatuto de Contratación Público de Colombia prevé que la responsabilidad contractual del Estado se sustenta en actuaciones antijurídicas.

\section{REFERENCIAS}

Aristóteles (2004). Ética a Nicómaco. Porrúa.

Balmes, J. (s.f.). Ética. Consultado el 15 de marzo de 2018. http://www.clerus.org/bibliaclerusonline/ pt/cik.htm

Bautista, O. D. (2009). Ética pública y buen gobierno. Instituto de Administración Pública del Estado de México.

Bilbeny, N. (1992). Aproximación a la ética. Ariel.

Camps, V. (2003). Virtudes públicas. Espasa-Calpe. 
Congreso de Colombia (1993, 28 de octubre). Ley 80 de 1993. Estatuto General de Contratación de la Administración Pública. Diario Oficial n. ${ }^{\circ}$ 41094. http://www.secretariasenado.gov.co/senado/basedoc/ ley_0080_1993.html

Congreso de Colombia (2011, 18 de enero). Ley 1437 de 2011. Código de Procedimiento Administrativo y de lo Contencioso Administrativo. Diario Oficial n. ${ }^{\circ}$ 47956. http://www.secretariasenado.gov. co/senado/basedoc/ley_1437_2011.html

Consejo de Estado de Colombia. Sala de lo Contencioso Administrativo. (2016, 27 de enero). Proceso 49847 (Jaime Orlando Santofimio Gamboa, C. P.). http://190.217.24.55:8080/WebRelatoria/ce/ index.xhtml

Consejo de Estado de Colombia. Sala de lo contencioso Administrativo. (2013, 24 de julio). Proceso 25642 (Enrique Gil Botero, C. P.). http://190.217.24.55:8080/WebRelatoria/ce/index.xhtml

Consejo de Estado de Colombia. Sala de lo Contencioso Administrativo. (2015, 8 de junio). Expediente 2005-01330-01 (Jaime Orlando Santofimio Gamboa, C. P.). http://190.217.24.55:8080/WebRelatoria/ ce/index.xhtml

Consejo de Estado de Colombia. Sala de lo Contencioso Administrativo. (2015, 29 de octubre). Radicación 66001233100020100034301 (Stella Conto Díaz del Castillo, C. P.). http://190.217.24.55:8080/ WebRelatoria/ce/index.xhtml

Consejo de Estado de Colombia. Sala de lo Contencioso Administrativo. (2005, 24 de agosto). Expediente 25000-23-26-000-2003-02458-01(AP) (María Elena Giraldo Gómez, C. P.). http://190.217.24.55:8080/WebRelatoria/ce/index.xhtml

Consejo de Estado de Colombia. Sala de lo Contencioso Administrativo. (2012, 25 de abril). Expediente 0500123250001994227901 (Enrique Gil Botero, C. P.). http://190.217.24.55:8080/WebRelatoria/ce/ index.xhtml

Consejo de Estado de Colombia. Sala de lo Contencioso Administrativo. (2011, 9 de mayo). Proceso 19976 (Jaime Orlando Santofimio Gamboa, C. P.). http://190.217.24.55:8080/WebRelatoria/ce/ index.xhtml

Consejo de Estado de Colombia. Sala de lo Contencioso Administrativo. (2016, 3 de noviembre). Proceso 29334 (Jaime Orlando Santofimio Gamboa, C.P.). http://190.21 7.24.55:8080/WebRelatoria/ ce/index.xhtml

Consejo de Estado de Colombia. Sala de lo Contencioso Administrativo. (2014, 27 de marzo). Expediente 1998-03066-01 (Danilo Rojas Betancourth, C. P.). http://190.217.24.55:8080/WebRelatoria/ce/ index.xhtml

Consejo de Estado de Colombia. Sala de lo Contencioso Administrativo. (2013, 24 de octubre). Proceso 24697 (Enrique Gil Botero, C. P.). http://190.21 7.24.55:8080/WebRelatoria/ce/index.xhtml

Consejo de Estado de Colombia. Sala de lo Contencioso Administrativo. (2009, 22 de julio). Proceso 17552 (Ruth Stella Correa Palacio, C. P.). http://190.217.24.55:8080/WebRelatoria/ce/index.xhtml

Consejo de Estado de Colombia. Sala de lo Contencioso Administrativo. (2010, 11 de agosto). Proceso 18499 (Mauricio Fajardo Gómez, C. P.). http://190.217.24.55:8080/WebRelatoria/ce/index.xhtml

Congreso de la República de Colombia (1991). Constitución Política de Colombia http://www.secretariasenado. gov.co/senado/basedoc/constitucion_politica_1991.html 
Congreso de los Diputados y del Senado (1978). Constitución de España. https://www.boe.es/legislacion/ documentos/ConstitucionCASTELLANO.pdf

Corte Constitucional de Colombia. (2006, 17 de marzo). Sentencia T-209 de 2006 (Jaime Córdoba Triviño, M. P.). https://www.corteconstitucional.gov.co/relatoria/2006/T-209-06.htm

Corte Constitucional de Colombia. (2009, 7 de octubre). Sentencia C-713 de 2009 (María Victoria Calle Correa, M. P.). https://www.corteconstitucional.gov.co/RELATORIA/2009/C-713-09.htm

Cortes Generales Españolas. (2015, 1 de octubre). Ley 39 de 2015. Procedimiento Administrativo Común de las Administraciones Públicas. Boletín Oficial del Estado n. ${ }^{\circ}$ 236. https://www.boe.es/buscar/act. php?id=BOE-A-2015-10565

Cortes Generales Españolas. (2017, 8 de noviembre). Ley 9 de 2017. Contratos del Sector Público. Boletín Oficial del Estado n. ${ }^{0}$ 272. https://www.boe.es/buscar/doc.php?id=BOE-A-2017-12902

Cortina, A. (2012). Ética mínima (15a ed.). Tecnos.

Estatuto de Contratación Pública de Colombia (1993) http://www.secretariasenado.gov.co/senado/ basedoc/ley_0080_1993.html

García, L. (2006). Ética o filosofía moral. Trillas.

García, E. (1977). Ética. Porrúa.

Guerra, Y. (2007). Responsabilidad del Estado por el actuar de sus funcionarios: Introducción al estudio de la corrupción. Universidad Libre de Colombia.

Guglielmi, G. y Koubi, G. (2011). Droit du service public (3e éd). Montchrestien.

Long, M. (2017). Les grands arrêts de la jurisprudence administrative (2le éd). Dalloz.

Monroy Cabra, M. G. (2000). Ética en la abogacía. Universidad de la Sabana.

Morand-Deville, J. (2010). Curso de derecho administrativo. Universidad Externado de Colombia.

Peña, L., Ausín, T. y Bautista, O. D. (2010). Ética y servicio público. Plaza y Valdés.

Platón. (2011). La República o el Estado (P. de Azcárate, trad.). Austral.

Quinche, M. F. (2015). Derecho Constitucional Colombiano (6 $6^{\mathrm{a}}$ ed.). Temis.

Rodríguez, J. (2012a). El interés general en el derecho administrativo: notas introductorias. https://revistascolaboracion.juridicas.unam.mx/index.php/opera-prima-derecho-admin/article/viewFile/1485/1385

Rodríguez, J. (2012b). El ciudadano y el poder público. Reus.

Villar, L. (2007, diciembre). Estado de derecho y Estado social de derecho. Revista Derecho del Estado, (20), 73-96. 